\title{
Effects of Minimum Quantity Lubrication (MQL) on cutting temperature, tool wear and surface roughness in turning AISI-1045 material
}

\author{
Tran Trong Quyet ${ }^{1}$, Luong Hong Sam ${ }^{1}$, Truong Minh Nhat ${ }^{2}$, Tran Anh Son ${ }^{2}$, Dao Thanh Liem², \\ Truong Quoc Thanh ${ }^{2, *}$
}

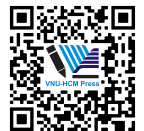

Use your smartphone to scan this QR code and download this article

${ }^{1}$ Tran Dai Nghia University, 189 Nguyen Oanh Street, District Go Vap, Ho Chi Minh City, Vietnam

${ }^{2}$ Ho Chi Minh City University of Technology, VNU-HCM, 268 Ly Thuong Kiet Street, District 10, Ho Chi Minh City, Vietnam

Correspondence

Truong Quoc Thanh, Ho Chi Minh City University of Technology, VNU-HCM, 268 Ly Thuong Kiet Street, District 10, Ho Chi Minh City, Vietnam

Email: tqthanh@hcmut.edu.vn

History

- Received: 16-10-2018

- Accepted: 02-01-2019

- Published: 31-12-2019

DOI : 10.32508/stdjet.v3iSI1.726

\section{Check for updates}

\section{Copyright}

(c) VNU-HCM Press. This is an openaccess article distributed under the terms of the Creative Commons Attribution 4.0 International license.

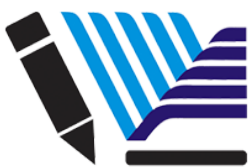

VNU-HCM Press

\section{ABSTRACT}

Nowadays, the effects of cutting fluids to health, environment, productivity and quality in machining operations have been discussed. The Minimum Quantity Lubrication (MQL) is green technology which is gradually applied in mechanical processing. This paper has introduced about MQL cooling lubrication method in mechanical processing. The previous researches have been made to clarify the meaning in MQM. In addition, the comparison of the outputs between MQL with dry and flood lubrications has also been shown the more effectiveness. Hence, based on the MQL equipment being used at Tran Dai Nghia University, the authors designed and fabricated a test rig to evaluate the impact of MQL parameters in machining process. This research focus on to presents of the MQL parameters optimization approach in which the multi-response outputs based on Taguchi's L9 orthogonal array method is used. During the turning AISI-1045 steel, the cutting temperature, the maximum of tool wear, and the surface roughness were measured. The MQL parameters which are ratio of soluble lubricant and water, pressure of spray head, flow volume of emulsion was simultaneously optimized by taking the multi-response outputs using Taguchi based grey relational analysis (GRA) into consideration. In turning experiments, three different flow volume of emulsion $Q(40,60,80 \mathrm{ml} / \mathrm{h})$, three different levels pressure of spray head $P(3,5,7$ bar $)$ and three different levels ratio of soluble lubricant and water $\mathrm{R}(4,6,8 \%)$ were used. Beside, three mathematical models were created using response surface regression methodology. The experiments had been done to investigate the effect of the MQL parameters to the turning process. As the results, the set of optimal MQL parameters had been pointed out to simultaneously minimize the cutting temperature, the tool wear and surface roughness. The Flow volume of emulsion $80 \mathrm{ml} / \mathrm{h}$, Pressure of spray head 7 bar, Ratio of soluble lubricant and water $6 \%$ was observed to be the most effective.

Key words: Minimum Quantity Lubrication (MQL), temperature cutting, tool wear, surface roughness, Grey Relational Analysis (GRA)

\section{INTRODUCTION}

Various cutting fluids have been employed to replace the "dry machining" in order to increase the ability machining. Because the cutting fluids improve the tool life and it generates a better surface quality, the efficiency of cutting process increases significantly. Proper selection of cutting fluids generally improves the tool life. Cutting fluid not only cools the tool and job but also provides lubrication and cleans the cutting zone and protects the nascent finished surface from contamination by the harmful gases present in the atmosphere. But the conventional types of cutting fluid have been found to become less effective with the increase in cutting velocity and feed when the cutting fluid cannot properly enter the chip-tool interface to cool and lubricate due to bulk plastic contact of the chip with the tool rake surface. Besides that, often in high production machining the cutting fluid may cause premature failure of the cutting tool by fracturing due to close curling of the chips and thermal shocks. The knowledge over the performance of cutting fluids when applied to different work materials and operations is of crucial importance in order to improve the efficiency of most conventional machining processes. This efficiency can be measured, among other parameters, through cutting tool life and work piece surface finish. However, the costs associated with the purchase, handling and disposal of cutting fluids are leading to the development of tool materials and coatings which do not require their application. Cutting fluid is used to take away the heat and to lubricate the machined surface. Cutting fluid should promote the tool life, improve the surface integrity of the work piece, flush the chips from the cutting zone and protect the surface from corrosion. Tradi- 
tionally, the machining of parts uses flood cooling in which the jet of coolant is directed toward the cutting zone. Here, the coolant is deployed in large quantities. There are several disadvantages to using this method. The first one has to do with the cost of machining and its disposal. Approximately fifteen percent of total cost in machining is incurred by the coolant and its disposal. The second one deals with a safety issue for the operators. One problem that exists for operators is that when they stay in contact with the coolant for a long time, it may cause skin problems. The third one is the effect on the environment. After machining, the chips produced are mixed with the cutting fluid and they cannot be disposed of directly as regular trash. At the same time, coolant should be filtered before being reused and after several more uses, the coolant also needs to be disposed. The chips and the used coolant are disposed as hazardous waste-a practice that is costly to any industry. Now, using the coolant in large quantities is a costly proposition that is not user friendly nor environmental friendly.

MQL technique uses a small quantity of oil or lubricant. It is mixed with compressed air to generate a mist or an aerosol. The mist particles provide lubrication and the compressed air helps to reduce the temperature during machining. The range of oil flow rate in MQL usually varies from $1 \mathrm{oz}$ to $8 \mathrm{oz}$ in 8 hours. This quantity is very small compared to flood cooling. The air pressure varies from 0.2 to 0.6 bar. It is showed that MQL helps to reduce the cutting temperature and dimensional inaccuracy when turning of AISI 1040 steel was cut by an uncoated carbide insert by ${ }^{1}$. Khan et al. ${ }^{2}$ performed turning on AISI 9310 alloy steel using vegetable oil-based cutting fluid and found that MQL produced the best surface finish over a wide range of machining time as compared to the wet and dry turning. This too could be due to the reduction in flank temperature by using MQL. Cetin et al., evaluated vegetable based cutting fluids with extreme pressure and cutting parameters in turning of AISI 304L and found that sunflower and canola based cutting fluids perform better than the others ${ }^{3}$. Kamata and Obikawa (2007) experimentally investigated high speed turning of Inconel-718 with different coated tools using the MQL technique and made a comparison between dry, wet and MQL techniques with regard to tool life and surface finish as ${ }^{4}$. The surface finish and tool life attained using MQL was found to be better than that in the wet and the dry machining for differently coated cutting tools.

Cutting fluids are used in machining processes to reduce friction at the tool-chip and tool-workpiece interfaces, to cool both the chip and the tool, and to remove chip. They have a strong effect on shearing mechanisms and, consequently, on machined surface quality and tool wear ${ }^{5}$. For companies, the costs related to cutting fluids represent a large amount of total machining costs. Research has found that the costs related to cutting fluids are frequently higher than those related to cutting tools. Moreover, cutting fluids have been found to cause health and social problems for workers, related to lubricant use and correct disposal $^{6}$. It is important to consider environmental factors (minimization of waste and human toxicity, and saving of cutting fluid) and economic factors (saving energy and improvement of production efficiency) at the same time. Therefore, several other technologies have been developed in recent years to solve these problems. Lawal et al. ${ }^{7}$ also assessed the various lubrication techniques in machining processes and makes a case for MQL technique using vegetable oil-based lubricant. They have concluded that MQL technique using vegetable oil-based lubricant in any machining processes offers the best alternative in combating the environmental problems. Dhar et al. ${ }^{8}$ during their investigation in turning AISI 1040 steel found that the use of MQL reduced the friction at tool chip interface and deterioration of effective rake angle by BUE formation and wear at the cutting edge. This could probably be attributed to the reduction in the cutting temperature. They also recorded reduced auxiliary flank wear as compared to dry turning. This too could be due to the reduction in flank temperature by using MQL. Hadad and Sadeghi ${ }^{9}$ found that among all the three types of turning (wet, dry and MQL) of AISI 4140 alloy steel, MQL produced the best surface quality for the entire range of depth of cut. They also noticed that minimum cutting force was required to perform turning operation with the MQL technique as compared to dry and wet turning for the entire depth of cut values. By using MQL, the cutting force was reduced by $40 \%$, the cutting temperature decreased by $36 \%$ and the surface finish improved by $30 \%$ as compared to dry turning ${ }^{10}$. According to the multi-response optimization results, which were obtained from the largest signal to noise ratio of the grey relational grade (GRG), the optimum combination was vegetable base cutting fluid, $180 \mathrm{~mL} / \mathrm{h}$ fluid flow rate and $30 \mathrm{~m} / \mathrm{min}$ cutting speed to simultaneously minimize the tool wear patterns and surface roughness. In addition, it was found out that the percentage improvement in GRG with the multiple responses is $39.4 \%{ }^{11}$.

Numerous studies have focused on compare the effects of three methods is dry cutting, wet cooling and MQL on the processing parameters. There are also 
numerous studies were parametric optimization of MQL technology with individual targets such as cutting temperature, tool wear and surface roughness. This study focuses on the influence of MQL parameters on cutting heat, tool wear and surface roughness. By using Taguchi based grey relational analysis (GRA) into consideration optimizing MQL parameters with multi-responses output.

\section{EXPERIMENTAL SETUP}

\section{Work piece material, machine tool, and cut- ting tool}

In this study, the AISI-1045 steel turning process was investigated. The material properties of work piece are presented in Tables 1 and 2 respectively. Dimension of the work piece was $\varnothing 60 \mathrm{~mm} \times 150 \mathrm{~mm}$. All the turning tests were performed by using a EATAP MA-1880 lathe machine that is equipped with a maximum spindle speed of $2800 \mathrm{rpm}$ and a $15 \mathrm{~kW}$ drive motor. Cutting tool parameter is showed in Table 3. The experiment model setup as showed in Figure 1.

\section{Cutting conditions and design of experi- ment}

MQL allows an aerosol spray, which is very minimum quantity, with balanced mixture of lubricant and air to the cutting zone ${ }^{12}$. Cutting fluid in MQL system was mixed with air through a nozzle and an air compressor and it was transferred to the interface of workpiece-cutting tool as shown in Figure 1. In turning experiments, three different flow volume of emulsion Q $(40,60,80 \mathrm{ml} / \mathrm{h})$, three different levels pressure of spray head $\mathrm{P}(3,5,7 \mathrm{bar})$ and three different levels ratio of soluble lubricant and water $\mathrm{R}(4,6,8 \%)$ were used. Overall the experimental conditions are given in Table 4.

According to a full factorial design, experimental design for three parameters with their three levels requires twenty-seven experiments. Machining time increases and cost raises an increase in process parameters or their levels. Taguchi's orthogonal array offers an opportunity to reduce the number of test compared to conventional design of experiment approach. In this study, according to control factors and their levels in Table 4, Taguchi's L9 orthogonal array was employed from the Minitab as shown in Table 5 for design of experiment.

\section{Measurement tools}

In machining process, surface roughness or surface quality is one of the most important quality indicators. In present work, the average values of surface roughness $(\mathrm{Ra})$ were measured after each experiment. Portable surface roughness tester model SJ-210 was conducted for Ra measurements. Before the measurements of surface roughness, measuring instrument was previously been calibrated with a known calibration block. Each surface was machined with a new cutting tool. After each experiment, measurements on the workpiece were carried out. In all tests, the values of surface roughness were measured on the different locations of workpiece to minimize the deviation and then a mean value of the surface roughness was calculated.

One point of the most important effects in tool wear is cutting temperature. In experiment, cutting temperature is measured. Thermal camera Testo $870-1$ model was used, with measurement range: $-20^{\circ} \mathrm{C}$ to $280^{\circ} \mathrm{C}$. Above tool wear, the maximum flank wear (VBmax) is measured. The insert was removed from the toolholder and wear was accurately determined through a professional microscope Jeol 5410 LV.

\section{RESEARCH METHODS}

This paper presents of the MQL parameters optimization approach in which the multi-response outputs based on Taguchi's L9 orthogonal array method is used. The MQL parameters which are ratio of soluble lubricant and water, pressure of spray head, flow volume of emulsion was simultaneously optimized by taking the multi-response outputs using Taguchi based grey relational analysis (GRA) into consideration. Here, three mathematical models were created using response surface regression methodology. The experiments had been done to investigate the effect of the MQL parameters to the turning process. As the results, the set of optimal MQL parameters had been pointed out to simultaneously minimize the cutting temperature, the tool wear and surface roughness.

\section{RESULTS AND DISCUSSION}

\section{Experiment results}

Based on Taguchi L9 orthogonal array consisting 9 sets of coded conditions and the experimental results for the responses are shown in Table 6.

Three mathematical models show the relationship of the output responses

Using Minitab 16, on Taguchi L9 orthogonal array method, three mathematical models were built to describe the relationship of the responses showed in Eq. $1-3$. 


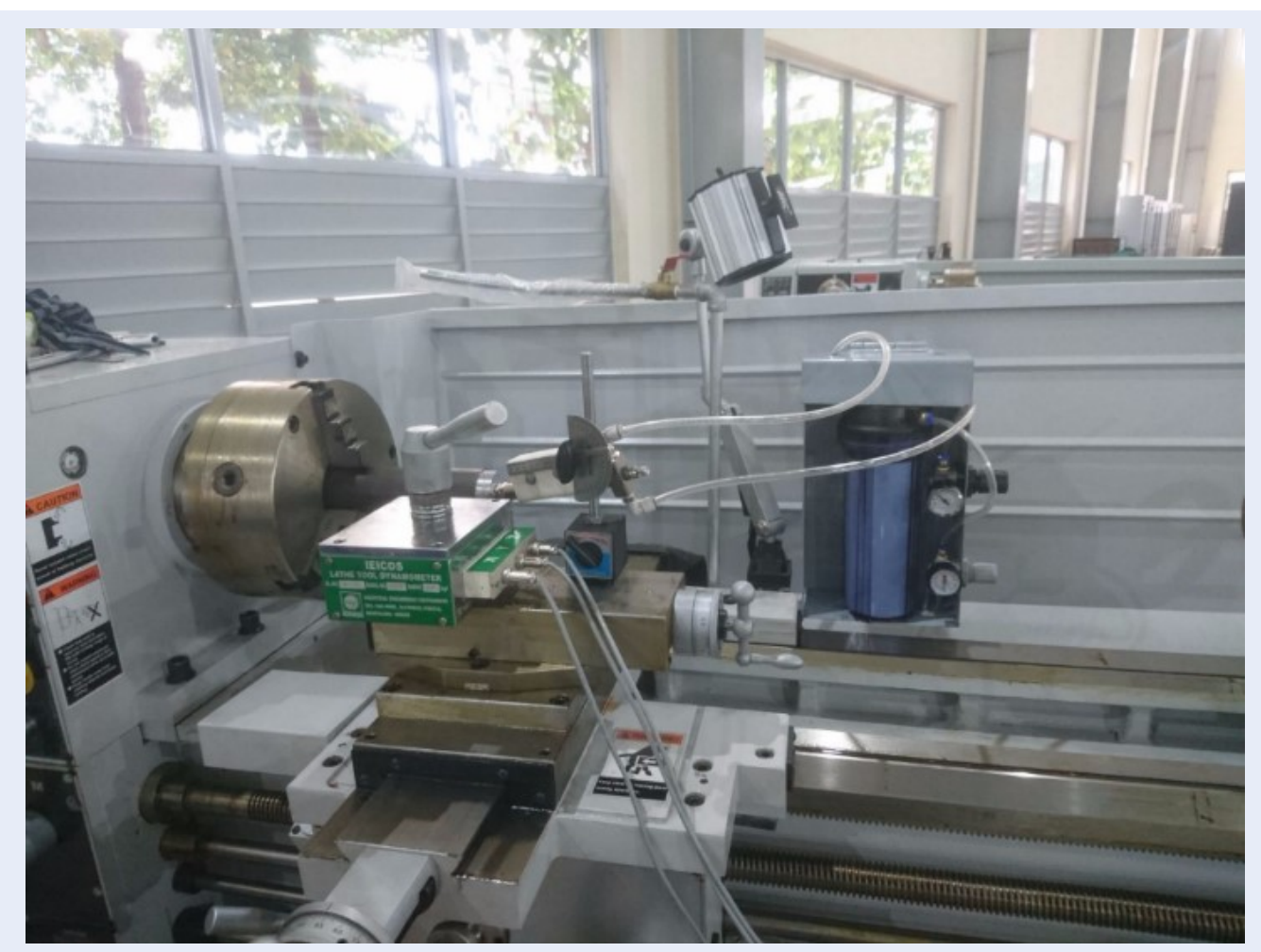

Figure 1: Experiment model.

Table 1: Chemical composition of AISI-1045 material

\begin{tabular}{llllclll}
\hline & & \multicolumn{5}{c}{ \% Weight } \\
C & Si & Mn & P max & S max & Cr max & Mo max & Ni max \\
$0.42-0.5$ & $0,17-0,37$ & $0.5-0.8$ & 0.04 & 0.04 & 0.25 & 0.1 & 0.25 \\
\hline
\end{tabular}

Table 2: Mechanical properties of material

\begin{tabular}{lllll}
\hline $\begin{array}{l}\text { Test temperature } \\
\left({ }^{\circ} \mathrm{C}\right)\end{array}$ & $\begin{array}{l}\text { Ultimate tensile } \\
\text { strength }(\mathrm{MPa})\end{array}$ & $\begin{array}{l}0.2 \% \text { Yield } \\
(\mathrm{MPa})\end{array}$ & $\begin{array}{l}\% \\
\text { Elong }\end{array}$ & $\begin{array}{l}\text { Hardness } \\
(\mathrm{HRC})\end{array}$ \\
Room & 610 & 360 & 16 & 23 \\
\hline
\end{tabular}

Table 3: Tool parameters

\begin{tabular}{ll}
\hline Item & Description \\
Cutting insert & Coated carbide, SNMG 120408-QM (S-15 grade) Sandvik H13A quality \\
Tool Holder & PSBNR2020K12 \\
Working tool & inclination angle: $-6^{\circ}$, clearance angle: $0^{\circ}$, \\
Geometry & rake angle: $-6^{\circ}$, major edge cutting angle: $75^{\circ}$ \\
& nose radius: $0.8 \mathrm{~mm}$ \\
\hline
\end{tabular}


Table 4: Experimental conditions

\begin{tabular}{ll}
\hline Item & Description \\
$\begin{array}{l}\text { Process parameters } \\
\text { Cutting speed (Vc) }\end{array}$ & $110 \mathrm{~m} / \mathrm{min}$ \\
Feed rate (f) & $0.15 \mathrm{~mm} / \mathrm{rev}$ \\
Depth of cut (t) & $1 \mathrm{~mm}$ \\
Cutting fluid (CFs) & $\begin{array}{l}\text { MQL condition } \\
\text { Mineral oil; viscosity at } 40 \mathrm{oC}: 46 \mathrm{~mm} 2 / \mathrm{s}, \text { density at } 20 \mathrm{oC}: 0.96 \mathrm{~g} / \mathrm{cm} 3, \text { flash point: } \\
\end{array}$ \\
& $154 \mathrm{oC}$, \\
\hline
\end{tabular}

\section{Table 5: Experimental design}

\begin{tabular}{lllllll}
\hline Exp. No. & Coded values & & \multicolumn{3}{c}{ Actual Values } \\
& A & B & C & Q (ml/h) & P (Bar) & R (\%) \\
1 & 1 & 1 & 1 & 40 & 3 & 4 \\
2 & 1 & 2 & 2 & 40 & 5 & 6 \\
3 & 1 & 3 & 3 & 40 & 7 & 8 \\
4 & 2 & 1 & 2 & 60 & 3 & 6 \\
5 & 2 & 3 & 60 & 5 & 8 \\
6 & 2 & 3 & 1 & 60 & 7 & 4 \\
7 & 3 & 1 & 3 & 80 & 3 & 8 \\
9 & 3 & 2 & 1 & 80 & 5 & 4 \\
\hline
\end{tabular}

Table 6: Experimental results

\begin{tabular}{lllllll}
\hline $\begin{array}{l}\text { Exp. } \\
\text { No. }\end{array}$ & \multicolumn{1}{l}{ Coded values } & & Result values \\
& A & B & C & $\begin{array}{l}\text { Cutting temp. Tmax } \\
\left({ }^{\circ} \mathrm{C}\right)\end{array}$ & $\begin{array}{l}\text { Tool wear VB max } \\
(\mu \mathrm{m})\end{array}$ & $\begin{array}{l}\text { Surface roughness Ra } \\
(\mu \mathrm{m})\end{array}$ \\
1 & 1 & 1 & 1 & 165.7 & 75 & 1.228 \\
2 & 1 & 2 & 2 & 161 & 76 & 1.105 \\
3 & 1 & 3 & 3 & 160.1 & 86 & 1.635 \\
4 & 2 & 1 & 2 & 161.5 & 81 & 1.465 \\
5 & 2 & 2 & 3 & 240.57 & 85 & 1.7 \\
6 & 2 & 3 & 1 & 175.9 & 83 & 1.368 \\
7 & 3 & 1 & 3 & 165.7 & 78 & 1.38 \\
\hline 8 & 3 & 2 & 1 & 163.5 & 80 & 1.148 \\
\hline
\end{tabular}




\section{Temperature cutting}

Response Table for Signal to Noise Ratios Smaller is better, the result show in Table 7 and Figure 2.

Table 7: Response Table for Means

\begin{tabular}{llll}
\hline Level & $\mathrm{Q}$ & $\mathrm{P}$ & $\mathrm{R}$ \\
1 & 162.3 & 164.3 & 168.4 \\
2 & 192.7 & 188.4 & 156.5 \\
3 & 158.7 & 161.0 & 188.8 \\
Delta & 33.9 & 27.4 & 32.3 \\
Rank & 1 & 3 & 2 \\
\hline
\end{tabular}

Regression Equation

$$
\begin{aligned}
& T_{\max }=123.1+6.572 * Q+46.86 * P \\
& -90.99 * R-0.08039 Q * Q-7.156 P * P \\
& +7.631 R * R+0.4222 P * Q+0.1458 Q * R
\end{aligned}
$$

\section{Tool wear}

Response Table for Signal to Noise Ratios Smaller is better, the result show in Table 8 and Figure 3 .

Table 8: Response Table for Means

\begin{tabular}{llll}
\hline Level & $\mathrm{Q}$ & $\mathrm{P}$ & $\mathrm{R}$ \\
1 & 79.00 & 78.00 & 79.33 \\
2 & 83.00 & 80.33 & 77.00 \\
3 & 77.33 & 81.00 & 83.00 \\
Delta & 5.67 & 3.00 & 6.00 \\
Rank & 2 & 3 & 1 \\
\hline
\end{tabular}

Regression Equation

$$
\begin{aligned}
& V B_{\max }=36.12+2.033 Q-0.6667 P \\
& -5.333 R-0.01208 Q * Q+0.2083 P * P \\
& +0.9167 R * R-0.02500 P * Q-0.08333 Q * R
\end{aligned}
$$

\section{Surface roughness}

Response Table for Signal to Noise Ratios Smaller is better. The results of means value and main effected value are shown in Table 9 and Figure 4, respectively. Regression Equation

$R a=0.3586+0.09559 Q-0.2623 P$

$-0.4407 R-0.000628 Q * Q+0.02004 P * P$
Table 9: Response Table for Means

\begin{tabular}{llll}
\hline Level & $\mathrm{Q}$ & $\mathrm{P}$ & $\mathrm{R}$ \\
1 & 1.323 & 1.354 & 1.376 \\
2 & 1.562 & 1.395 & 1.239 \\
3 & 1.299 & 1.434 & 1.568 \\
Delta & 0.263 & 0.081 & 0.328 \\
Rank & 2 & 3 & 1 \\
\hline
\end{tabular}

Multi-response optimization using grey relational analysis (GRA)

The GRA is principally employed to perform a relational analysis of the ambiguity of a system model and deficiency of information. It can create discrete sequences for the correlation analysis of such sequences with processing uncertainty, multi-factors and discrete data. It is a measurement method to determine the degree of approximation among the sequences with the help of grey relational grade (GRG). So, in this paper GRG was employed to determine the optimal combination of turning parameters that minimize three responses such as Tmax, VBmax and Ra simultaneously. To achieve this goal, after the normalization of the experimental results, GRG was determined to assess the multiple responses. In the GRA, the first step is to perform the normalization of experimental data to make the range within $0-1$. This step is called grey relational generating. According to the importance of quality characteristics, this can be divided into three criteria for optimization in GRA, namely "larger-the-better," "smaller-the-better," and "nominal-the-best" 13 .

In this paper, smaller the value of tool wear patterns and smaller the surface roughness are desirable. Therefore, calculation method of "smaller the better" was employed since minimization of the Tmax, VB$\max$ and $\mathrm{Ra}$ is intended. So, the smaller-the-better

(2) should be described in the following equation:

$$
x_{i} p=\frac{\max \left(x_{i}^{0}(p)\right)-\left(x_{i}^{0}(p)\right)}{\max \left(x_{i}^{0}(p)\right)-\min \left(x_{i}^{0}(p)\right)}
$$

here $\mathrm{x}_{i}(\mathrm{p})$ is the value after grey relational generation, $\max \left(x_{i}^{0}(p)\right)$ and $\min \left(x_{i}^{0}(p)\right)$ are the largest and smallest values of $x_{i}^{0}(p)$ for the $\mathrm{p}_{t h}$ response, respectively. The values of the Tmax, the VBmax and Ra are set to be the reference sequence, $\mathrm{p}=1-3$. The responses of nine tests are the comparability series $x_{i}^{0}(p), \mathrm{i}=1,2,3$, $\ldots, 9, \mathrm{p}=1-3$. All sequences after application the data preprocessing through Eq. (4) are shown in Table 10. Actually, in order to obtain the better performance, the larger normalized results should be expected, 



Figure 3: Main effects plot for S/N ratio on flank wear max. 




Figure 4: Main effects plot for $\mathrm{S} / \mathrm{N}$ ratio on surface roughness.

therefore; best normalized result should be equal to one. Further, the grey relational coefficient $\left(\mathrm{x}_{i}(\mathrm{p})\right)$ is assigned to explain the relation between desirable and real experimental normalized data. Grey relational coefficient is defined as follows:

$$
\zeta(p)=\frac{\triangle_{\min }+\zeta \triangle_{\max }}{\triangle_{0 i(p)}+\zeta \triangle_{\max }}
$$

Here, $\triangle_{0 i(p)} \square=$ difference of the absolute value between $\mathrm{x}_{0}(\mathrm{p})$ and $\mathrm{x}_{i}(\mathrm{p}), \triangle_{\min }$ and $\triangle_{\max }$ and are respectively the minimum and maximum values of the absolute differences of all comparing sequences. $\zeta$ is the distinguishing or identification coefficient, and its value lies between 0 and $1, \zeta \in[0-1]$, the aim of which is to weaken the influence of $\triangle_{\max }$ when it gets too big and besides enlarges the difference significance of relational coefficient. Generally, the distinguishing coefficient is assumed as 0.5 to fit the practical requirements. Therefore, in the present study, $\zeta$ was taken as 0.5 . The grey relational coefficients calculated using Eq. (5) and Table 11 listed these coefficients.

Then, grey relational coefficient GRG expresses the level of correlation between the reference and comparability sequences. GRG is a weighted sum of the Grey relational coefficients, and is calculated as follows:

$$
y_{i}=\frac{1}{n} \sum_{p-1}^{n} \zeta(p)
$$

Table 10: Normalized values

\begin{tabular}{llll}
\hline $\begin{array}{l}\text { Exp. } \\
\text { no. }\end{array}$ & $\begin{array}{l}\text { Cutting temper- } \\
\text { ature } \mathrm{T}_{\max }\end{array}$ & $\begin{array}{l}\text { Tool wear } \\
\mathrm{VB}_{\max }\end{array}$ & $\begin{array}{l}\text { Surface } \\
\text { roughness } \\
\mathrm{Ra}\end{array}$ \\
1 & 0.800 & 0.917 & 0.793 \\
2 & 0.850 & 0.833 & 1.000 \\
3 & 0.860 & 0.000 & 0.109 \\
4 & 0.845 & 0.417 & 0.395 \\
5 & 0.000 & 0.083 & 0.000 \\
6 & 0.691 & 0.250 & 0.303 \\
7 & 0.800 & 0.667 & 0.558 \\
8 & 0.824 & 0.500 & 0.538 \\
9 & 1.000 & 1.000 & 0.928 \\
\hline
\end{tabular}

In the last step of GRA, Table 12, which was calculated using Eq. (6), identified as the highest GRG and $\mathrm{S} / \mathrm{N}$ ratio in the first order. According to the performed experiment design, Table 12 demonstrate that the MQL parameters setting of 9 (test no. 9) has the highest GRG. Thus, the nine experiment gives the best multi-performance characteristics among the other experiments to determine the simultaneous minimum temperature cutting and minimum tool wear and minimum surface roughness. 


\begin{tabular}{llll}
\multicolumn{4}{l}{ Table 11: Grey relational coefficient } \\
\hline Exp No. & $\begin{array}{l}\text { Cutting } \\
\text { perature } \\
\mathrm{T}_{\max }\end{array}$ & $\begin{array}{l}\text { Tool wear } \\
\mathrm{VB}_{\max }\end{array}$ & $\begin{array}{l}\text { Surface } \\
\text { roughness } \\
\mathrm{Ra}\end{array}$ \\
1 & 0.714 & 0.857 & 0.707 \\
2 & 0.770 & 0.750 & 1.000 \\
3 & 0.781 & 0.333 & 0.360 \\
4 & 0.763 & 0.462 & 0.452 \\
5 & 0.333 & 0.353 & 0.333 \\
6 & 0.618 & 0.400 & 0.418 \\
7 & 0.714 & 0.600 & 0.531 \\
8 & 0.739 & 0.500 & 0.520 \\
9 & 1.000 & 1.000 & 0.874 \\
\hline
\end{tabular}

\begin{tabular}{llll}
\multicolumn{4}{l}{ Table 12: GRG, S/N ratio and its orders } \\
\hline Exp No. & Grade & S/N ratio & Orders \\
1 & 0.760 & -6.554 & 3 \\
2 & 0.840 & -5.637 & 2 \\
3 & 0.491 & -9.040 & 7 \\
4 & 0.559 & -8.086 & 6 \\
5 & 0.340 & -9.378 & 9 \\
6 & 0.479 & -8.406 & 8 \\
7 & 0.615 & -7.491 & 4 \\
8 & 0.586 & -7.567 & 5 \\
9 & 0.958 & -5.969 & 1 \\
\hline
\end{tabular}

The optimal parametric combination was found as $\mathrm{Q}$ (level 3), P (level 3) and R (level 1) whose details are below:

Flow volume of emulsion: $80 \mathrm{ml} / \mathrm{h}$

Pressure of spray head: 7 bar

Ratio of soluble lubricant and water: $6 \%$.

\section{CONCLUSION}

This paper has presented an application of Taguchi method in the optimization of parameters of MQL system for turning operations. The following conclusions can be drawn based on the experimental results of this study:

- It can be found that Taguchi method provides a simple methodology for the optimization of the machining process and reduce experiment time and cost.
- The results of experiments show that among the three controllable factors of MQL system (Flow volume of emulsion, Pressure of spray head, Ratio of soluble lubricant and water) that air pressure and ratio of emulsion are the main parameters influence surface roughness in turning structure AISI-1045 steel.

- Three mathematical models were created the relationship of the output responses.

- The Flow volume of emulsion $80 \mathrm{ml} / \mathrm{h}$, Pressure of spray head 7 bar, Ratio of soluble lubricant and water $6 \%$ was observed to be the most effective.

\section{ACKNOWLEDGMENTS}

This research was supported by Engineering faculty, Ho Chi Minh City University of Technology and Basic Engineering faculty, Tran Dai Nghia University. Thanks you for your technology, equipment and financial support.

\section{ABBREVIATIONS}

MQL: minimum quantity lubrication

GRA: grey relational analysis

GRG: grey relational grade

S/N: Signal-To-Noise

ANOVA: The Analysis of Variance

VBmax: maximum flank wear

Q: flow volume of emulsion

Ra: surface roughness

R: Ratio of soluble lubricant and water

Tmax: Maximum temperature cutting zone

\section{CONFLICT OF INTEREST:}

The authors hereby warrant that this paper is no conflict of interest with any publication.

\section{AUTHOR'S CONTRIBUTION}

MSc. Tran Trong Quyet provided experimental ideas, practiced experiments, synthesized research publications and analyzed the experimental data.

Ass. Prof. Luong Hong Sam conducted the idea of equipment design and suggested optimization method by using GRA.

MSc. Truong Minh Nhat and Dr. Dao Thanh Liem measured the out parameters and analyzed the results. Dr. Truong Quoc Thanh played a role as a corresponding author. 


\section{REFERENCES}

1. Dhar NR, Kamruzzaman M, Ahmed M. Effect of minimum quantity lubrication (MQL) on tool wear and surface roughness in turning AISI-4340 steel. Journal of Materials Processing Technology. 2006;172(2):299-304. Available from: https: //doi.org/10.1016/j.jmatprotec.2005.09.022.

2. Khana MMA, Mithua MAH, B NRD. Effects of minimum quantity lubrication on turning AISI 9310 alloy steel using vegetable-oil based cutting fluid. Journal of Materials Processing Technology. 2009;209. Available from: https://doi.org/10. 1016/j.jmatprotec.2009.05.014.

3. a M Huseyin Cetin BO, Kuram E, Demirbas E. Evaluation of vegetable based cutting fluids with extreme pressure and cutting parameters in turning of AISI 304L by Taguchi method. Journal of Cleaner Production. 2011;

4. Kamata Y, Obikawa T. High speed MQL finish-turning of Inconel 718 with different coated tools. Journal of Materials Processing Technology. 2007;192-193:281-286. Available from: https://doi.org/10.1016/j.jmatprotec.2007.04.052.

5. Diniz $A E$, Ferreira JR, Filho FT. Influence of refrigeration/lubrication condition on SAE 52100 hardened steel turning at several cutting speeds. International Journal of Machine Tools and Manufacture. 2003;43(3):317-326. Available from: https://doi.org/10.1016/S0890-6955(02)00186-4.

6. Weinert IIK, Sutherland JW, Wakabayashi T. Dry Machining and Minimum Quantity Lubrication. 2004;

7. Lawal SA, Choudhury IA, Nukman Y. A critical assessment of lubrication techniques in machining processes: a case for minimum quantity lubrication using vegetable oil-based lu- bricant. Journal of Cleaner Production. 2013;41:210-221. Available from: https://doi.org/10.1016/j.jclepro.2012.10.016.

8. Dhar NR, Islam MW, Islam S, Mithu MAH. The influence of minimum quantity of lubrication (MQL) on cutting temperature, chip and dimensional accuracy in turning AISI-1040 steel. Journal of Materials Processing Technology. 2006;171(1):9399. Available from: https://doi.org/10.1016/j.jmatprotec.2005. 06.047 .

9. Hadad M, Sadeghi B. Minimum quantity lubrication-MQL turning of AISI 4140 steel alloy. Journal of Cleaner Production. 2013;54:332-343. Available from: https://doi.org/10.1016/j. jclepro.2013.05.011.

10. Lohar DV, Nanavaty CR. Performance Evaluation of Minimum Quantity Lubrication (MQL) using CBN Tool during Hard Turning of AISI 4340 and its Comparison with Dry and Wet Turning. Bonfring International Journal of Industrial Engineering and Management Science. 2013;Available from: https://doi.org/10. 9756/BIJIEMS.4392.

11. Sarıkaya M, Güllü A. Multi-response optimization of minimum quantity lubrication parameters using Taguchi-based grey relational analysis in turning of difficult-to-cut alloy Haynes 25. Journal of Cleaner Production. 2015;91:347-357. Available from: https://doi.org/10.1016/j.jclepro.2014.12.020.

12. Tasdelena B, Wikblomb T, Ekeredc S. Studies on minimum quantity lubrication $(\mathrm{MQL})$ and air cooling at drilling. Journal of materials processing technology. 2008;200. Available from: https://doi.org/10.1016/j.jmatprotec.2007.09.064.

13. Deng JL. Introduction to grey system theory. The Journal Grey System. 1989;1:1-24. 


\title{
Ảnh hưởng của bôi trơn tối thiểu (MQL) đến nhiệt cắt, độ mòn dao và độ nhám bề mặt khi tiện thép AISI -1045
}

\author{
Trần Trọng Quyết ${ }^{1}$, Lương Hồng Sâm ${ }^{1}$, Trương Minh Nhật ${ }^{2}$, Trần Anh Sơn ${ }^{2}$, Đào Thanh Liêm² \\ Trương Quốc Thanh ${ }^{2, *}$
}



Use your smartphone to scan this QR code and download this article

${ }^{1}$ Truơơng Đại học Trân Đại Nghĩa, 189 Nguyễn Oanh, Phường 10, Gò Vấp, TP.HCM, Việt Nam

${ }^{2}$ Trường Đại học Bách khoa, ĐHQG-HCM, 268 Lý Thuiơng Kiệt Quân 10, TP.HCM, Việt Nam

Liên hệ

Trương Quốc Thanh, Trường Đại học Bách khoa, ĐHQG-HCM, 268 Lý Thường Kiệt, Quận 10, TP.HCM, Việt Nam

Email: tqthanh@hcmut.edu.vn

Lịch sử

- Ngày nhận: 16-10-2018

- Ngày chấp nhận: 02-01-2019

- Ngày đăng: 31-12-2019

DOI : 10.32508/stdjet.v3iSI1.726

\section{Check for updates}

\section{Bản quyền}

๑๑ ĐHQG Tp.HCM. Đây là bài báo công bố mở được phát hành theo các điều khoản của the Creative Commons Attribution 4.0 International license.

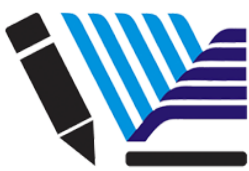

VNU-HCM Press

\section{TÓM TẮT}

Những ảnh hưởng của quá trình bôi trơn lên sức khoẻ, môi trường, năng suất và chất lượng của quá trình gia công cắt kim loại đã được thảo luận. Phương pháp bôi trơn tối thiếu (MQL) là một "công nghệ xanh" được ứng dụng rộng rãi trong quá trình gia công cơ. Có rất nhiều nghiên cứu liên quan đến phương pháp này ở các nghiên cứu trước đây. So sánh kết quả đầu ra của phương pháp bôi trơn tối thiểu giữa khô và ướt để đánh giá hiệu quả phương pháp này. Sử dung thiết bị thí nghiệm ở Trường Đại học Trần Đại Nghĩa, nhóm tác giả thiết kế thực nghiệm để đánh giá ảnh hưởng của những thông số trong phương pháp bôi trơn tối thiếu lên kết quả đầu ra. Gia công trên bộ thông số đó, và tối ưu hóa chúng. Mục đích của nghiên cứu này là tối ưu thông số MQL với đa thông số đâu ra dựa vào thiết kế ma trận thực nghiệm trực giao Taguchi L9. Những thông số nhiệt độ cắt, độ mòn dao và độ nhám bề mặt được đo lường trong quá trình tiện thép AISI-1045. Các thông số tî̉ lệ chất bôi trơn và nước, áp suất đầu phun, lưu lượng phun được xem như những thông số biến đổi và được tối ưu hóa dựa vào kết quả của ba thông số đầu ra sử dụng phân tích quan hệ mờ (GRA). Thực nghiệm tiện được thực hiện với các mức thông số khác nhau, lưu lượng phun (40,60, 80 ml/ giờ), áp suất đầu phun (3, 5, 7 bar), tỉ lệ chất bôi trơn và nước (4, 6, 8\%). Thông qua phương pháp phân tích đáp ứng bề mặt ba mô hình toán mô tả ảnh hưởng của những thông số MQL lên các thông số đầu ra được xây dựng. Các thí nghiệm đã được thực hiện để điêu tra ảnh hưởng của các tham số MQL đến quá trình tiện. Từ những kết quả phân tích và quy hoạch, một bộ thông số MQL tối ưu đã được đưa ra để đông thời nhiệt độ cắt, độ mòn dao và độ nhám bề mặt là nhỏ nhất. Với lưu lượng phun 80 ml/giờ, áp suất đầu phun 7 bar, tỉ lệ chất bôi trơn và nước 6\% cho hiệu quả gia công tốt nhất.

Từ khoá: Phương pháp bôi trơn tối thiểu, Nhiệt độ cắt, Độ mòn dao, Độ nhám bề mặt, Phân tích mối quan hệ mờ
Trích dẫn bài báo này: Quyết $T T$, Sâm $L H$, Nhật $T M$, Sơn $T A$, Liêm $D T$, Thanh $T Q$. Ảnh hưởng của bôi trơn tối thiểu (MQL) đến nhiệt cắt, độ mòn dao và độ nhám bề mặt khi tiện thép AISI -1045. Sci. Tech. Dev. J. - Eng. Tech.; 2(SI1):SI92-SI102. 